\title{
DIALEKTIKA INKLUSIVISME DAN EKSKLUSIVISME ISLAM KAJIAN SEMANTIK TERHADAP TAFSIR AL-QURAN TENTANG HUBUNGAN ANTARAGAMA
}

\author{
Rofiq Nurhadi \\ Fakultas Keguruan dan Ilmu Pendidikan Universitas Muhammadiyah Purworejo \\ Email: rofiq_nurhadi@yahoo.co.id \\ Syamsul Hadi \\ Fakultas Ilmu Budaya Universitas Gadjah Mada
}

Thoyib I. M.

Fakultas Sastra Universitas Al-Azhar Indonesia

Suhandano

Fakultas Ilmu Budaya Universitas Gadjah Mada

\begin{abstract}
Potentially, both inclusivism and exclusivism can emerge from Islam itself. To an extreme point, inclusive point of view underline the importance to apprecieate religious pluralism and to avoid truth claims. To the other extreme, exlusive point of view suspect and even reject pluralism and upholds truth claims. Islam may be presented by the two extremes, and it is not only because of defferent emphasis in reading the holy texts, but also because of defferent methodologies of interpretation being employed. This paper discusses different methodologi of interpretation that determinate significantly the meaning of din, millah and syari' ah and how they are related. The one that uses the relation of synonymy avoid ta'ārud al-adillah reading (the dispute among axioms) so leads to inclusive comprehension. The other using the relation of hyponymy between din and syarī'ah leads to ta'arud reading, uses of nasikh wa al-mansūkh method (abrogation), and so leads to exclusive comprehension.
\end{abstract}

Keywords: Inclusivism, exclusivism, synonymy, and hyponymy.

\begin{abstract}
ABSTRAK
Secara potensial, inklusivisme, dan eksklusivisme dalam Islam bisa lahir dari Islam itu sendiri. Pada titik ekstrim, pandangan inklusif menggaris bawahi pentingnya mengapresiasi kebinekaan dan menghindari klaim kebenaran. Sebaliknya pandangan eksklusif' mencurigai bahkan menolak kebinekaan dan melakukan klaim kebenaran. Perbedaan dalam menghadirkan Islam itu selain disebabkan adanya perbedaan penekanan dalam pembacaan teks-teks suci, juga disebabkan oleh perbedaaan dalam metodologi penafsiran. Perbedaan metodologi penafsiran yang sangat signifikan adalah perbedaan dalam menentukan relasi makna antara dīn, millah dan syarî'ah. Relasi sinonimi menghindarkan pembacaan ta'ārud al-adillah (pertentangan antar dalil) sehingga sampai pada pemahaman yang inklusif. Sementara relasi hiponimi antara dīn, dan syarī'ah mengantarkan pada pembacaan ta'ārud dan berdampak pada penggunaan metode nasikh wa al-mansūkh (membatalkan dan dibatalkan) sehingga hadir pemahaman yang eksklusif.
\end{abstract}

Kata kunci: Inklusivisme, eksklusivisme, sinonimi, dan hiponimi. 


\section{PENGANTAR}

Pluralitas merupakan realitas yang harus dihadapi oleh Islam. Penerimaan atau penolakan terhadapnya merupakan problem kehidupan beragama. Bila pluralitas atau kebinekaan diterima sebagai suatu keniscayaan bagaimana dengan misi suci keagamaan untuk menghimpun umat ke dalam Islam. Bila ditolak bagaimana dengan visi kerahmatannya? Sebagaimana ditegaskan dalam al-Qur'an sendiri bahwa kehadiran Islam tiada lain adalah untuk menebar rahmat (QS. al-Anbiya [21]: 107). Demikian kegelisahan yang lahir dari kesadaran beragama ditengah-tengah pluralitas atau kemajemukan.

Kalau dilihat dalam khasanah tafsir alQur'ān sebagai pemegang otoritas untuk menjelaskan pandangan yang Qur'ani, disana nampak ada dua pandangan teologis yang secara ekstrim saling bertolak belakang. Dua pandangan teologis mengenai Islam dalam hubungannya dengan agama-agama lain itu adalah inklusivisme dan eksklusivisme. Kedua pemikiran ini dalam tafsir selalu terbuka untuk diperdebatkan. Model penafsiran secara riwayat yang dianggap sebagai model penafsiran yang utama nampak belum menuntaskan persoalan dan masih menyisakan ketegangan. Tafsir riwayat disebut juga at-tafsir bin-naql atau attafsir bil ma'tsur, yaitu rangkaian keterangan yang terdapat dalam al-Qur'ān, as-Sunnah atau kata-kata Shahabat sebagai keterangan atau penjelasan terhadap maksud Allah (firmanNya) (as-Shabuny, 1981: 63).

Dari sini perlu perspektif baru atau integrasi berbagai disiplin keilmuan untuk melerai atau setidak-tidaknya mengurangi ketegangan debat inklusivisme dan eksklusivisme Islam tersebut. Dalam tulisan ini penulis bermaksud menghadirkan semantik sebagai cabang ilmu bahasa untuk ikut andil melerai ketegangan tersebut. Perbedaan penafsiran terhadap kata din, millah and syari'ah yang menyebabkan perbedaan pandangan antara inklusivisme dan eksklusivisme Islam akan dikaji dari sisi semantik.

\section{PEMBAHASAN \\ Pengertian Inklusivisme dan Eksklusivisme serta Perkembangan Wacananya dalam Islam.}

Mengawali kajian tentang dialektika, inklusivisme dan eksklusivisme dalam Islam berikut akan dibahas pengertian kedua istilah tersebut. Dalam bahasa Inggris inclusive sebagai kata sifat artinya adalah including everything (Bull, 2011: 224). Adapun exclusive yang juga sebagai kata sifat, artinya adalah "(1) only to be used by or given to one particular person or group; (2) (of a group) admitting only carefully chosen people; (3) of a high quality and expensive and therefore not used by many people" (Bull, 2011: 153).

Setelah masuk ke dalam perbendaharaan kata Indonesia inclusive berubah menjadi inklusif dan exclusive menjadi eksklusif. Inklusif artinya termasuk dan terhitung (Tim Penyusun Kamus Pusat Bahasa, 2008: 589). Adapun eksklusif artinya terpisah dan khusus (Tim Penyusun Kamus Pusat Bahasa, 2008: 379). Dari sini dapat disimpulkan bahwa inklusif secara bahasa adalah terbuka sebaliknya eksklusif adalah tertutup.

Selanjutnya setelah dinisbatkan pada agama muncul istilah "teologi inklusivis". Menurut Alwi Shihab teologi ini dikaitkan dengan pandangan Karl Rehner, seorang teolog Katolik, yang intinya menolak asumsi bahwa Tuhan mengutuk mereka yang tidak berkesempatan meyakini Injil. Mereka yang mendapatkan anugerah cahaya Ilahi walaupun tidak melalui Yesus, tetap akan mendapatkan keselamatan (Shihab, 1999: 84). Senada dengan ini, Nurcholis Madjid ia memaknai inklusivisme Islam dalam dua hal.

Pertama, pandangan terhadap agamaagama lain sebagai bentuk implisit dari agama tertentu.

Kedua, sikap terbuka dan toleran terhadap penganut agama non-Islam (Madjid, 1992: 234).

Adapun teologi eksklusif -masih dari paparan Alwi Shihab- dalam dunia Kristen, eksklusivis berarti kebahagiaan abadi hanya dapat dicapai melalui Yesus, dan 
hanya mereka yang percaya pada-Nya yang selamat (Shihab, 1999: 84). Senada dengan ini Nurcholish Madjid menyatakan sikap eksklusif dalam melihat agama lain adalah melihat agama-agama lain sebagai jalan yang salah, yang menyesatkan bagi pengikutnya (Madjid, 1999: xix).

Baik pandangan inklusif ataupun eksklusif dalam Islam memiliki dasar skriptual yang cukup memadai. Pandangan teologi inklusivis dalam Islam menggaris bawahi ayat-ayat al-Qur'an, antara lain:

"Sesungguhnya orang-orang mukmin, orang-orang Yahudi, orang-orang Nasrani dan orang-orang Shabiin, siapa saja diantara mereka yang benar-benar beriman kepada Allah, hari kemudian dan beramal saleh, mereka akan menerima pahala dari Tuhan mereka, tidak ada kekhawatiran kepada mereka, dan tidak (pula) mereka bersedih hati" (QS. al-Baqarah [2]: 62).

Pesan ayat ini diulang dalam redaksi yang hampir mirip dalam QS. al-Maidah [5]: 69.

"Sesungguhnya orang-orang mukmin, orang-orang Yahudi, Shabiin dan orangorang Nasrani, siapa saja (diantara mereka) yang benar-benar saleh, maka tidak ada kekhawatiran terhadap mereka dan tidak (pula) mereka bersedih hati."

Kedua ayat ini menjanjikan keselamatan penganut agama Kristen, Yahudi, dan Shabiin, yang percaya kepada keesaan Tuhan, pengadilan hari kemudian, dan menghiasi diri dengan amal kebajikan.

Adapun pandangan eksklusivis dalam teologi Islam antara lain mendasarkan pada pemahaman ayat,

"Sesungguhnya agama (yang diridhai) disisi Allah hanyalah Islam. Tiada berselisih orang-orang yang telah diberi al-Kitab kecuali sesudah datang pengetahuan kepada mereka, karena kedengkian (yang ada) di antara mereka. Barangsiapa yang kafir terhadap ayat-ayat Allah, maka sesungguhnya Allah sangat cepat hisabNya" (QS Ali Imran [3]: 19).

dan juga ayat:

"Barangsiapa mencari agama selain agama Islam, maka sekali-kali tidaklah akan diterima (agama itu) daripadanya, dan dia di akhirat termasuk orang-orang yang rugi" (QS Ali Imran [3]: 85).

Seiring dengan perkembangan dunia yang sangat cepat dan globalisasi yang telah menjadikan dunia menjadi satu, menjadi dunia yang polisentris, multi-kultural dan multi-religius, wacana inklusivisme Islam juga semakin menguat. Harapannya adalah agar Islam ikut memberi andil bagi upayaupaya perdamaian dunia global yang multireligius ini. Sebagaimana disadari banyak pihak bahwa peran agama memang sangat penting bagi upaya-upaya perdamaian dunia. Hans Kung menyebutnya bahwa, 'Tidak ada perdamaian dunia tanpa perdamaian antaragama'. (Kung, 1999: xvii).

Diantara para pakar yang menggulirkan wacana inklusivisme Islam ini adalah Ismail Raji al-Faruqi. Dalam paparannya, ia menjelaskan bahwa asal semua agama adalah satu, karena bersumber pada yang satu, Tuhan. Agama yang menjadi asal semua agama ini disebutnya Ur-Religion atau "agama fitrah" (din al-fithrah) yang bersifat meta-religion, sebagaimana firman Allah

"Maka hadapkanlah wajahmu kepada (Allah) dengan lurus; tetaplah atas fitrah Allah yang telah menciptakan manusia diatas fitrah itu. Tidak ada perubahan pada fitrah Allah. Itulah agama yang benar, akan tetapi, kebanyakan manusia tidak mengetahui" (QS. Ar-Rum [30]: 20).

Islam mengidentikkan dirinya dengan "agama fitrah" ini. Tetapi kemudian, sejalan dengan tingkat perkembangan sejarah, peradaban dan lokasi umat yang menerimanya, "agama fitrah" atau UrReligion tersebut berkembang menjadi agama historis atau tradisi agama yang spesifik dan beraneka (plural) (Faruqi, 1982: 102-105).

Nurcholish Madjid dalam bukunya Tiga Agama Satu Tuhan, ia menulis, "Sebagai sebuah pandangan keagamaan, pada dasarnya Islam bersifat inklusif dan merentangkan tafsirnya ke arah yang semakin pluralis. Sebagai contoh filsafat perenial yang belakangan banyak dibicarakan dalam dialog antaragama di Indonesia merentangkan pandangan pluralis 
dengan mengatakan bahwa setiap agama sebenarnya merupakan ekspresi keimanan terhadap Tuhan yang sama. Ibarat roda, pusat roda itu adalah Tuhan, dan jari-jari itu adalah jalan dari berbagai agama. Filsafat perenial juga membagi agama pada level esoterik (batin) dan eksoterik (lahir). Satu agama berbeda dengan dengan agama lain dalam level eksoterik, tetapi relatif sama dalam level esoteriknya. Oleh karena itu ada istilah "Satu Tuhan Banyak Jalan" (Madjid, 1999: xix).

Kemudian Alwi Shihab (1999: 108109) menyebutkan bahwa eksklusivisme keagamaan tidak sesuai dengan semangat al-Qur'ān sebab al-Qur'ān tidak membedabedakan antara satu komunitas agama dari lainnya. Prinsip ini digariskan oleh dua ayat al-Qur'ān, sebuah eksposisi yang jarang sekali terjadi sebuah ayat al-Qur'an tampil dua kali dan hampir mirip kata per kata, yang menyatakan:

"Sesungguhnya mereka telah beriman, Yahudi, Kristen dan Kaum Shabiin; Mereka yang percaya pada Tuhan dan hari akhir dan berbuat kebaikan, akan menerima pahala dari Tuhan mereka. Mereka tidak akan merugi, dan tidak akan berduka cita" (QS. Al-Baqarah [2]: 62, QS. al-Māidah [5]: 69).

Seiring dengan semakin mengemukanya pandangan teologi inklusif yang berkembang kearah pluralisme ini, muncul pula upayaupaya pertahanan terhadap pandangan teologi eksklusif yang dianggap sebagai upaya untuk menjaga kemurnian aqidah (teologi) Islam dari pencemaran teologi inklusif maupun pluralis yang menurutnya membawa pada sinkritisme dan relativisme. Sementara yang lain seraya menyadari akan realitas pluralitas yang tak terelakkan, kepentingan untuk mempertahankan kemurnian aqidah tersebut juga merupakan suatu yang tidak bisa ditawar-tawar. Usaha untuk menjebatinya misalnya dengan membagi ajaran Islam kepada ajaran tentang aqidah, ibadah, dan mu'amalah (sosial). Eksklusivisme itu harus dipertahankan pada wilayah akidah (teologi) dan ibadah (ritual), sementara dalam masalah sosial yang tidak berkaitan dengan akidah dan ibadah, berlaku sikap inklusif sepanjang tidak saling merugikan (Majelis Ulama Indonesia, 2011: 91-92).

Dari sini kesadaran akan realitas pluralitas juga melahirkan sikap yang beragam. Menurut Richard J. Mouw dan Sandra Griffioen sebagaimana yang di kutip oleh Syamsul Hidayat bahwa sikap terhadap keberagaman itu bisa dibagi menjadi dua.

Pertama, deskriptif yaitu sekadar mengakui keragaman.

Kedua, normatif-preskriptif yang tidak sekadar mengakui, tetapi juga mau memperjuangkan keragaman.

Pada tataran deskriptif, keberagaman (pluralisme) adalah fakta sosial yang tidak terelakkan, baik karena kondisi awal masyarakatnya sudah majemuk maupun karena proses pluralisasi kehidupan yang dibawa oleh arus modernisasi. Selanjutnya pada tataran normatif-preskriptif, terdapat tiga ranah keragaman, yaitu konteks budaya (contextual pluralism), asosiasi-asosiasi kelembagaan (associational pluralism), dan sistem nilai yang memberi arahan pada kehidupan manusia (directional pluralism). (Hidayat, 2012: 39)

\section{Perbedaan Penafsiran}

Suatu hal yang mendasari dialektika inklusivisme dan eksklusivisme Islam ini adalah perbedaan penafsiran terhadap teksteks suci. Secara eksklusif, QS Ali Imran [3]: 19 menyatakan:

(inna ad-dìna 'inda Allahi al-islāmu) "sesungguhnya ad-dīn disisi Allah hanyalah islam.",

dan QS Ali Imran [3]: 85 menyatakan: (wa man yabtaghi ghaira al-islämi dìnan falan yaqbala minhu wa huwa fi al-äkhirati min al-khāsirìn) "barangsiapa mencari ad-dīn selain islam, maka sekali-kali tidaklah akan diterima (ad-dīn itu)daripadanya, dan dia di akhirat termasuk orang-orang yang rugi."

Ayat ini ditafsirkan bahwa agama yang benar hanyalah Islam yaitu agama yang disyariatkan pada Nabi terakhir Muhammad saw. 
Berbeda dengan pandangan diatas, pandangan inklusif melihat kata الاسلام (alislām) dalam QS Ali Imran [3]: 19 dan 85 tersebut bukanlah islam dalam pengertian "organized religion", tetapi الاسلام (al-islām) dalam arti kata generiknya, yaitu "tunduk atau berserah diri". Jadi الدين (ad-din) disisi Allah hanyalah tunduk dan beserah diri pada Allah. Selanjutnya Allah sengaja jadikan untuk tiap-tiap umat asy-syarī'at dan jalan yang terang, karena Allah hendak menguji mana yang paling baik diantara umatnya, sebagaimana firmanNya:

(....li kulli ja'alnā minkum syir'atan wa minhajan, walau syā̄a Allāhu laja'alakum ummatan wāhidatan walākin liyabluwakum fì mā àtākum, fastabiqū al-khairāt) “....untuk tiap-tiap umat diantara kamu, Kami berikan syari'at dan jalan yang terang. Sekiranya Allah menghendaki, niscaya kamu dijadikan-Nya satu umat (saja), tetapi Allah hendak menguji kamu terhadap pemberianNya kepadamu, maka berlomba-lombalah berbuat kebajikan...." (QS al-Maidah [5]: 48).

BahkanumatMuhammad-pun diperintahkan untuk mengikuti millah Ibrahim sebagaimana diungkapkan al-Quran:

(qul shadaqallahu, fattabi'ū millata ibrähima hanifān wamā kāna mina al-musyrikin) "Katakanlah: Benarlah (apa yang difirmankan) Allah. Maka ikutilah millah Ibrahim yang lurus, dan bukanlah dia termasuk orang-orang yang musyrik." (QS. Ali Imran [3]: 95)

Secara riwayat pandangan eksklusif mendapatkan sandaran pada asbab an-nuzul yang diriwayatkan oleh as-Sady bahwa ayat:

"Sesungguhnya orang-orang mukmin, orang-orang Yahudi, orang-orang Nasrani dan orang-orang Shabiin, siapa saja diantara mereka yang benar-benar beriman kepada Allah, hari kemudian dan beramal saleh, mereka akan menerima pahala dari Tuhan mereka, tidak ada kekhawatiran kepada mereka, dan tidak (pula) mereka bersedih hati" (QS al-Baqarah [2]: 62).

Ayat ini turun berkaitan dengan sahabatsahabat Salmān al-Fārisy. Suatu ketika Salmān menceritakan pada Nabi perihal sahabat-sahabatnya. Ungkapnya,"bahwa mereka itu berpuasa, shalat dan beriman padamu serta mereka menyaksikan bahwa engkau bakal diutus sebagai nabi". Setelah selesai Salmān memuji-muji para sahabatnya itu, nabi Muhammad saw berkata padanya, "wahai Salmān, mereka semua ahli neraka." Apa yang disampaikan Nabi ini menjadikan Salmān sangat sedih. Maka Allah menurunkan ayat ini.

Asbāb an-nuzul ini dipahami oleh Ibnu Katsir, bahwa imannya Yahudi adalah bahwa mereka memegangi Taurat dan sunnahnya Musa 'alaihi as-salam sampai datang 'Isa. Ketika telah datang Isa, maka siapa saja yang memegangi Taurat dan mengambil sunnahnya Musa, tidak meninggalkan sunnahnya Musa dan tidak mengikuti Isa maka mereka binasa. Adapun imannya Nashara adalah bahwa mereka memegangi Injil dan sunnahnya Isa, maka mereka itu disebut mukmin dan diterima keimanan mereka sampai datang Muhammad saw. Ketika telah datang Muhammad mereka tidak mengikutinya serta tidak meninggalkan sunnahnya 'Isa dan Injil, maka mereka akan binasa (Ibnu Katsir, 1999: 1, 284)

Kesimpulan ini nampaknya diperoleh Ibnu Katsir setelah memproyeksikan kehidupan sahabat-sahabat Salmān yang dikatakan nabi sebagai ahli neraka itu adalah sebelum kerasulan Muhammad. Karena bila diproyeksikan mereka masih hidup pada masa kerasulan Muhammad justru bantahan Allah dalam QS. al-Baqarah [2]: 62 terhadap sabda nabi Muhammad tersebut menunjukkan bahwa sahabat-sahabatSalmān (yang tidak mengikuti nabi Muhammad) itu bisa masuk surga asalkan beriman pada Allah dan hari akhir serta beramal shalih. Tapi kesimpulan yang diambil oleh Ibnu Katsir adalah hukum jaminan keselamatan pada Yahudi, Nasrani, dan Shabi'in dalam QS al-Baqarah [2]: 62 itu hanya sebatas kurun waktu sebelum diutusnya nabi Muhammad saw tidak sesudahnya.

Adapun dalam pandangan yang inklusif, QS al-Baqarah [2]: 62 tersebut. ditafsirkan bahwa keselamatan di akhirat itu tidak tergantung pada jenis agama seseorang, akan 
tetapi tergantung pada keimanannya yang benar dan amalnya yang baik. Keimanan yang benar itu tidak disyaratkan dengan mengimani Nabi Muhammad Saw (Ridha, 1947: 1, 336).

Berdasarkan riwayat Ibnu Jarīr dan ibnu Abi Hātim dari as-Sadiy, maka keselamatan disisi Allah itu bukan hanya karena anganangan orang Islam atau angan-angan Ahlul Kitab. Di dalam riwayatitu diceritakan bahwa telah bertemu orang-orang Islam, orangorang Yahudi dan orang-orang Nasrani. Orang-orang Yahudi berkata kepada orangorang Islam, "kami lebih baik dari kamu, agama kami lebih dulu dari agama kamu, kitab kami lebih dulu dari kitab kamu, nabi kami lebih dulu dari nabi kamu. Kami ini pengikut nabi Ibrahim dan tidak akan masuk syurga kecuali ia beragama Yahudi. Kemudian orang-orang Nasrani juga berkata yang sama dengan orang-orang Yahudi.

Selanjutnya, orang-orang Islam berkata, kitab kami setelah kitab kamu, nabi kami nabi Muhammad saw setelah nabi kamu, agama kami setelah agamamu. Telah diperintahkan kamu untuk mengikuti kami dan meninggalkan agamamu, kami lebih baik dari kamu, kami ini mengikuti agama Ibrahim, Ismail dan Ishaq. Tidak akan masuk syurga kecuali orang yang berada dalam agama kami. Dari peristiwa ini Allah menurunkan QS. an-Nisa' [4]: 123:

"(Pahala dari Allah) itu bukanlah menurut angan-anganmu yang kosong dan tidak (pula) menurut angan-angan ahli Kitab. Barangsiapa yang mengerjakan kejahatan, niscaya akan diberi pembalasan dengan kejahatan itu dan ia tidak mendapat pelindung dan tidak (pula) penolong baginya selain dari Allah" (Ridha, 1947: 1, 336)

Dengan demikian pada dasarnya agamaagama ini menyediakan jalan keselamatan, jalan keselamatan bukan monopoli satu agama tertentu, namun dalam perjalanan historisnya, setiap agama memiliki potensi yang sama untuk menyimpang, terutama secara normatif.

\section{Perbedaan Metodologi Penafsiran}

Apabila dilihat dari sudut pandang linguistik, nampak adanya perspektif yang berbeda dalam membaca teks-teks suci yang membincanghubungan antaragama sehingga menghasilkan penafsiran yang berbeda. Unsur bahasa dìn, millah, dan syarī'ah dalam teks-teks suci tersebut diinterpretasikan relasi maknanya secara berbeda. Pertama, syari'at itu ada di dalam ad-dinn. Di dalam addin yang hanya satu itu ada banyak syarī'at. Ad-din yang satu itu adalah islam, dan di dalam ad-dìn al-islām itu ada banyak syarī'at.

Dalam pandangan ini al-Qur'ān menggunakan kata syaríah dalam arti yang lebih sempit dari kata din yang biasa diterjemahkan dengan agama. Syarí'ah adalah jalan terbentang untuk satu umat tertentu dan nabi tertentu, seperti syarì'ah Nūh, syarī'ah Ibrāhīm, syarī'ah Mūsā, syarī'ah 'İsā, dan syarī'ah Muhammad saw. Sedangkan dìn/ agama adalah tuntunan Ilahi yang bersifat umum dan mencakup semua umat. Dengan demikian, agama dapat mencakup sekian banyak syarī'ah. (Shihab, 2009: III, 139) Bila digambar hubungan din dan syaríah disini adalah sebagai berikut

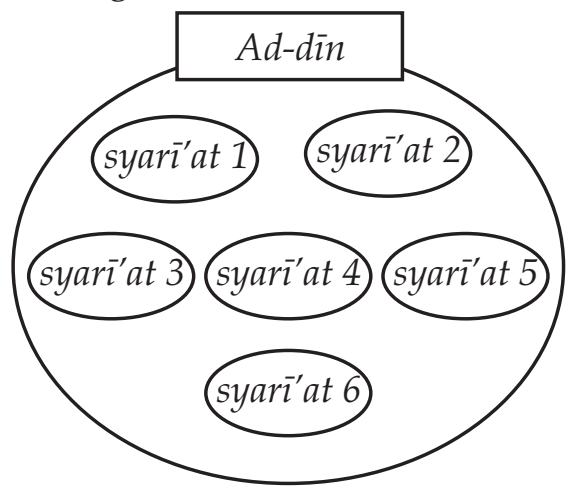

Diagram 1. Hubungan ketercakupan berbagai syarī'ah di dalam ad-dìn

Dilihat dari sisi relasi maknanya diagram 1 adalah relasi hiponimi. Hiponimi adalah hubungan semantik antara sebuah bentuk ujaran yang maknanya tercakup dalam makna bentuk ujaran yang lain (Chaer, 2007: 297).

Ketika teori hiponimi ini digunakan untuk membaca ayat: 
(...li kulli ja'alnā minkum syir'atan wa minhajan, walau syā'a Allāhu laja'alakum ummatan wāhidatan walākin liyabluwakum fi mā ātākum, fastabiqū al-khairāt) “....untuk tiap-tiap umat diantara kamu, Kami berikan syari'at dan jalan yang terang. Sekiranya Allah menghendaki, niscaya kamu dijadikan-Nya satu umat (saja), tetapi Allah hendak menguji kamu terhadap pemberianNya kepadamu, maka berlomba-lombalah berbuat kebajikan...." (QS al-Maidah [5]: 48).

dan ayat:

(inna ad-dina 'inda Allahi al-islāmu) "sesungguhnya ad-dīn disisi Allah hanyalah islam.", (QS Ali Imran [3]: 19)

maka yang terjadi adalah terjadinya $t a^{\prime} a \bar{r} u d$ (tampak saling bertentangan) antara kedua ayat tersebut.

Sesuai dengan teori hiponimi juga maka solusi medologisnya adalah penghapusan. Dalam relasi makna hiponimi pengambilan makna salah satu hiponimnya sudah dapat dibayangkan nama superordinatnya (kelompoknya) dan kalau yang disebut superordinatnya maka sudah termasuk di dalamnya semua hiponimnya, kecuali bila penyebutannya dengan memberikan ciri-cirinya. Superordinat adalah kata yang berada pada tingkat atas dalam sistem hierarki relasi hiponimi sedang hiponim adalah anggota-anggota yang berada pada tingkat bawahnya (Pateda, 2001: 209-210).

Dengan demikian bila di dalam ad-din itu banyak syari'at, maka penunjukan asysyari'at tertentu sudah dapat dibayangkan ad-din sebagai nama kelompoknya, dan bila disebut ad-din dengan ciri-ciri tertentu maka maknanya merujuk pada asy-syarī'at tertentu. Jadi bila yang disebut adalah ad-din al-Islam (QS Ali Imran [3]: 19), maka maknanya adalah syari'at Nabi terakhir, yaitu Muhammad saw. Adapun syari'at-syari'at yang lain adalah dinafikan atau dibatalkan (dihapuskan).

Penafsiran yang demikian ini menggunakan metode naskh. Naskh adalah mencabut hukum syari'at dengan dalil syari'at (raf'u al-hukmi asy-syar'iyyi bi dalilin syar'iyyin). Dimana beberapa ketentuan hukum syari'at yang oleh asy-Syari' (Allah daan Rasul-Nya) dipandang tidak perlu dipertahankan, dicabut dengan dalil-dalil yang kuat dan jelas serta berdasarkan kenyataan yang dapat dimengerti untuk kepentingan suatu hikmah yang hanya dapat diketahui oleh orang-orang yang berilmu sangat dalam (as-Shalih, 2004: 367).

Dalam hal ini adalah naskh juz'i, yakni pembatalan sebagian hukum syara' yang umum sebelumnya oleh hukum yang datang kemudian (Baidan, 2011: 173). Jadi ayat (....li kulli ja'alnà minkum syir'atan wa minhajan...,) "untuk tiap-tiap umat diantara kamu, Kami berikan syari' at dan jalan yang terang". (QS. al-Maidah [5]: 48)

di-naskh (naskh juz'i) oleh ayat (inna addina 'inda Allahi al-islāmu) "sesungguhnya ad-dīn disisi Allah hanyalah islam.", (QS Ali Imran [3]: 19). Dimana ketetapan banyaknya syari' at dalam QS. al-Maidah [5]: 48 itu telah dihapus sebagiannya oleh QS Ali Imran [3]: 19.

Dari sini penafsirannya adalah syari'atsyari'at sebelum syari'at nabi Muhammad Saw. hukumnya dibatalkan (dinaskh) sejak diturunkannya syari'at terakhir pada nabi Muhammad. (Shihab, 2009, vol 3: 137). Selanjutnya, (...., fastabiqū al-khairāt) "berlomba-lombalah menuju khairat" (QS. al-Maidah [5]: 48) sebagai kelanjutan dari ayat ini adalah anjuran untuk bersegera mentaati Allah dan mengikuti syari'at-Nya yang dijadikan sebagai penaskh terhadap syari'at-syari'at sebelumnya (Ibnu Katsīr, 1999: III, 130).

Jadi, setelah turun syari'at Muhammad maka ayat ini berfungsi sebagai seruan untuk masuk agama Islam, agama yang dibawa oleh Nabi Muhammad saw. Penganut Taurat dan Injil yang semasa dengan Nabi Muhammad saw. diwajibkan mengikuti dan mengamalkan tuntunan al-Qur'ān dan tidak lagi mengikuti kedua kitab yang turun sebelumnya (Taurat dan Injil) karena yang berkewajiban mengikuti keduanya adalah umat-umat yang lalu (Shihab, 2009: III, 141).

Berdasarkan penggunaan teori nashmansūkh (mencabut dan dicabut atau membatalkan dan dibatalkan) ini, maka 
meskipun disisi Allah semua agama yang dibawa oleh para Rasul adalah Islam -sejak Adam hingga akhir zaman- dan yang tidak menganut agama sesuai yang diajarkan oleh rasul yang diutus kepada mereka Allah tidak menerimanya, namun kata islam dalam ayat "Sesungguhnya ad-din (yang diridhai) disisi Allah hanyalah Islam" (QS Ali Imran [3]: 19) adalah ajaran yang dibawa oleh Nabi Muhammad saw (Shihab, 2009: II, 49).

Dengan demikian agama yang diridhai Allah dan memperoleh keselamatan di akhirat kelak (QS Ali Imran [3]: 85) adalah Islam yang menunjuk pada syari'at yang dibawa oleh Muhammad saw. Syarīat terdahulu dihapuskan oleh syari'at yang datang berikutnya. Sehingga syarī'at nabi Muhammad saw menghapuskan berlakukanya syarī'at-syaríat sebelumnya. Maka ad-din yang benar dan diridhai Allah pada masa kerasulan Muhammad saw adalah ad-din yang di dalamnya berisi syari'at islam yang disyariatkan pada nabi Muhammad saw (Shihab, 2009, vol 2: 48).

Dengan diterapkannya metode naskhmansūkh ini, bisa juga dipahami bahwa jaminan keselamatan pada Yahudi, Nasrani dan Shabi in dalam QS al-Baqarah [2]: 62 telah dinaskh (dihapus) oleh QS Ali Imran [3]: 85. Dasarnya adalah riwayat Ibnu Abbas yang menceritakan bahwa setelah menurunkan QS al-Baqarah [2]: 62 Allah menurunkan QS Ali Imran [3]: 85 (Ibnu Katsir, 1999: I, 284285). Artinya setelah diturunkan syari'at Muhammad maka jaminan keselamatan terhadap agama mereka dihapus dan wajib bagi mereka mengikuti syari'at nabi Muhammad saw.

Namun penggunaan metode naskhmansūkh dalam penafsiran ayat-ayat tentang hubungan antaragama ini tidak bebas dari kritik. Pasalnya bila QS. al-Baqarah [2]: 62 tersebut di-naskh, bagaimana dengan ayat yang semisal yang dengan redaksi yang mirip justru pada surat yang menurut kronologi turunnya lebih akhir dari surat Ali Imran, yaitu pada surat al-Maidah [5]: 69 (Amal, 2001: 87-88). Artinya bertentangan dengan teori naskh-mansükh yang menjelaskan bahwa ayat yang terdahulu yang dihapus oleh ayat yang turun kemudian (ayat nāsikhāt datang kemudian dari mansūkhāt) (Baidan, 2011: 175). Apalagi ayat ini adalah ayat teologis. Muhammad Abu Zahrah menyebutkan bahwa persoalan aqidah (teologi) adalah termasuk persoalan yang tidak dapat dinasakh (diganti). Karena ia adalah merupakan aturan yang bersifat abadi sebagaimana dapat dipahami dari firman Allah:

"Dia telah mensyari'atkan bagi kamu tentang agama apa yang telah diwasiatkanNya kepada Nuh dan apa yang telah Kami wahyukan kepadamu dan apa yang telah Kami wasiatkan kepada Ibrahim, Musa dan Isa, yaitu; Tegakkanlah agama dan janganlah kamu berpecah belah tentangnya." (QS as-Syura [42]:

13) (Zahrah, 2005: 187)

Kedua, secara umum din bermakna millah dan syarīah. Dilihat dari sisi taklif ("beban tanggung jawab manusia pada Tuhan") secara umum ketiganya bermakna sama. (Ridha, 1947, vol 3: 257). Bila digambar hubungan ketiga unsur bahasa tersebut adalah sebagai berikut,

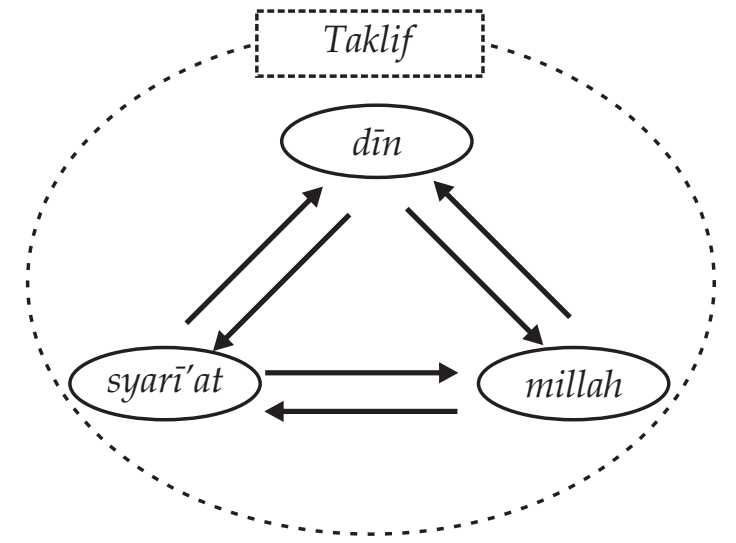

Diagram 2. Hubungan semakna antara dìn, millah dan syarīat

Dilihat dari sisi relasi maknanya diagram 2 adalah relasi makna sinonimi. Sinonimi adalah hubungan semantik yang menyatakan adanya kesamaan makna antara satu satuan ujaran dengan satuan ujaran lainnya (Chaer, 2007: 297). Dalam relasi makna sinonimi penggambilan makna merujuk pada konteks sinonimitasnya. Ketika ad-din itu sama dengan asy-syarī'at, 
maka makna dari keduanya merujuk pada makna sinonimitasnya, begitu juga din dengan millah.

Penerapan relasi makna sinonimi dalam penafsiran al-Qur'ān adalah tidak mempertentangkan atau menghadaphadapkan ayat secara diametral dalam penafsiran. Dengan teori sinonimitas, maka ayat-ayat yang mengandung unsur-unsur sinonimi tidak bisa dipertentangkan (dita'ārud -kan), sebab makna ketiga unsur bahasa itu bisa saling disubtitusikan. Dengan demikian model penafsiran ini tidak menghadapi persoalan $t a^{\prime} a \bar{r} u d$ (pertentangan antar ayat) dan persoalan naskh-mansūkh.

Sinonimitas kata ad-din dalam ayat QS Ali Imran [3]: 19 dan 85 dengan kata asysyari'at dalam QS al-Maidah [5]: 48 menuntut pemaknaan kata al-islām dalam QS Ali Imran [3]: 19 dan 85 pada arti kata generiknya, yaitu "tunduk atau berserah diri", bukan islam dalam pengertian "organized religion." Hal ini untuk menghindari ta'ārud (pertentangan). Jadi ad-din disisi Allah hanyalah tunduk dan beserah diri pada Allah. Adapun syaríatsyari'at yang diciptakan untuk tiap-tiap umat itu juga disebut ad-din. Allah menciptakan banyak syarī'at dan jalan yang terang karena Allah hendak menguji mana yang paling baik diantara umatnya (QS al-Maidah [5]: 48).

Begitu juga sinonimitas din dengan millah, maka perintah untuk mengikuti millah Ibrahim dalam QS. Ali Imran [3]: 95 adalah perintah untuk menetapi (taklif Allah, yaitu) tauhid yang murni dan ikhlas kepada Allah swt, dan yang demikian ini juga menjadi makna islam. Jadi kata millah disini adalah pokok dari agama, bukan mengikuti syari'atsyari'at dan hukum-hukum yang terperinci (Ridha, 1947, vol 6: 417-418) karena syari'at Allah itu bermacam-macam (Ridha, 1947: VI, 417). Syari'at yang bermacam-macam itu berfungsi sebagai pendidikan untuk memudahkan manusia melaksanakan beban taklifnya (Ridha, 1947, vol 3: 258) yaitu tunduk dan patuh pada Allah swt.

Jadi prinsip sinonimitas ini menyampaikan pada makna-makna yang dianggap subtansial yang mempertemukan ketiga unsur bahasa ini. Din dalam ayat 'din disisi Allah adalah islam' (QS Ali Imran [3]: 19) artinya tunduk dan patuh (terhadap taklif Allah), sehingga orang islam yang sebenarnya adalah orang yang bersih dari berbagai bentuk kemusyrikan pada Allah, ikhlas dalam amalnya bersama iman dari millah apapun, di zaman kapanpun dan tempat manapun (Ridha, 1947: III, 257).

Penafsiran yang demikian memandang Islam secara inklusif. Ia menggaris bawahi bahwa keselamatan itu bukan monopoli satu agama tertentu. Firman Allah dalam QS. al-Baqarah [2]: 62 dipahami bahwa semua penganut agama ilähiyah (yang diwahyukan Tuhan) yang telah sampai pada mereka dakwah nabi, apabila mereka beriman pada Allah dan hari akhir dengan cara yang benar yang telah dijelaskan oleh nabi mereka dan mereka beramal shalih, maka mereka memperoleh keselamatan dan mendapat balasan dari sisi Allah swt (Ridha, 1947, I: 339) Tidak ada syarat iman pada Nabi Muhammad saw, karena setiap umat yang beriman dibangun atas wahyu secara khusus. Keselamatan dan keberuntungannya di akhirat tidak dikarenakan ia Muslim, Yahudi, Nasrani atau Shabi'in. Keselamatannya tidak tergantung pada jenis agamanya tapi tergantung pada imannya yang benar dan amalnya yang shalih (Ridha, 1947: 1, 336).

\section{SIMPULAN}

Dilihat dari sisi cara pandang terhadap pluralitas, Islam bisa menghadirkan dua pandangan yang pada titik ekstrimnya saling bertolak belakang, yaitu eksklusif dan inklusif. Eksklusivisme mengarah pada absolutisme sedang inklusivisme mengarah pada relativisme dan sinkretisme. Dalam rentangan sayapnya inklusivisme membelah ke dalam dua tataran pandangan yaitu inklusif deskriptif yakni sekadar mengakui keragaman dan inklusif normatifpreskriptif yaitu tidak sekadar mengakui pluralitas, tetapi juga mau memperjuangkan keragaman.

Dalam perspektif linguistik, metodologi interpretasi teks inklusivisme, dan 
eksklusivisme ini berpijak pada metode yang berbeda. Din, millah, dan syari'ah yang merupakan tiga unsur bahasa kunci yang berbicara tentang hubungan antaragama dalam al-Qur'ān dipandang secara berbeda relasi maknanya. Dalam pandangan inklusivisme Islam ketiga unsur bahasa itu memiliki relasi sinonimi. Implikasi metodologi penafsiran teksnya adalah tidak menghadap-hadapkan teks yang mengandung ketiga unsur sinonimitas tersebut secara diametral, kerena ketiga unsur bahasa tersebut maknanya bisa saling disubtitusikan. Dari sini dalam penafsiran teksnya metode yang demikian ini terhindar dari persoalan $t a^{\prime} a \bar{r} u d$ al-adillah.

Berbeda dengan pandangan diatas, eksklusivisme Islam melihat din dan syari'ah memiliki relasi makna hiponimi. Implikasi pandangan ini dalam penafsiran teks adalah menculnya problem $t a^{\prime} \bar{a} r u d$. Adapun jalan keluarnya yang sesuai dengan relasi kedua unsur bahasa tersebut adalah naskh juz $i$ (penghapusan sebagian). Dimana bila yang disebut din dengan ciri islam sebagai superordinatnya maka yang dimaksud adalah syari'ah tertentu yang sesuai dengan ciri tersebut yaitu syari'at Muhammad saw sebagai hiponimnya. Sedang syarī'atsyarī' at yang lain tidak dimaksudkan dalam panggilan din al-islam tersebut.

\section{DAFTAR PUSTAKA}

Amal, T.A., 2001, Rekonstruksi Sejarah alQuran, Yogyakarta: Forum kajian Budaya dan Agama (FkBA)

Baidan, N, 2011, Wawasan Baru Ilmu Tafsir, Yogyakarta: Pustaka Pelajar

Bull, V, (ed.), 2011, Oxford Learner's Pocket Dictionary, New York: Oxford University Press.

Chaer, A, 2007, Linguistik Umum, Jakarta: Rineka Cipta

Faruqi, I.R. al-, 1982, Islam dan Agama-agama Lain, dalam Altaf Gauhar (ed.),
Tantangan Islam, Diterjemahkan oleh Anas Mahyuddin, Bandung: Penerbit Pustaka

Hidayat,S,2012,Tafsir DakwahMuhammadiyah: Respon terhadap Pluralitas Budaya, Kartasura: Kafilah Publishing.

Ibnu Katsīr, A, 1999 M/ 1420 H, Tafsir alQur'ān al-'Adhìm, Ar-Riyādh: Dar Thayibah li an-Nasyr wa at-Tauzī.

Kung, H, dan Kuschel, K.J., 1999, Etik Global, Terjemah Ahmad Murtajib. Yogyakarta: Sisipus bekerjasama dengan Pustaka Pelajar.

Madjid, N, 1992. Islam, Doktrin dan Peradaban: Sebuah Telaah Kritis Tentang Masalah Keimanan, Kemanusiaan dan Kemodernan, Jakarta: Paramadina.

Madjid, N, 1999, Tiga Agama Satu Tuhan, Bandung: Mizan

Majelis Ulama Indonesia, 2011, Himpunan Fatwa MUI Sejak 1975, Jakarta: Penerbit Erlangga.

Pateda, M, 2001, Semantik Leksikal, Jakarta: PT Rineka Cipta.

Ridha, S.M.R., 1947, Tafsir al-Qur'an al-Hakim: Tafsir al-Manar, Mesir: Dar al-Manar.

Shabuniy, M.'A., 1981, At-Tibyan fi 'Ulumil Qur'ān, Damaskus: Maktabah alGhazali.

Shalih, S, 2004, Membahas Ilmu-ilmu al-Qur'an, Terjemah Tim Pustaka Firdaus, Jakarta: Pustaka Firdaus.

Shihab, A, 1999, Islam Inklusif: Menuju Sikap Terbuka dalam Beragama, Bandung: Mizan

Shihab, M.Q., 2009, Tafsir al-Mishbah, Jakarta: Lentera Hati

Tim Penyusun Kamus Pusat Bahasa, 2008, Kamus Bahasa Indonesia, Jakarta: Pusat Bahasa.

Zahrah, M.A., 1958, Ushūl al-Fiqh, Kairo: Dār al-Fikr al-'Arabī 